\title{
Overview of Tracksite
}

This tracksite was discovered in 2007 as part of a comprehensive paleontological survey of the lower Cantwell Formation within Denali National Park. Here we show an aerial view of the tracksite which shows the precarious nature of the site (Fig. DR1). It is currently broken into five tilted fault blocks which are moving down slope.

\section{Invertebrate Trace Fossils and Modern Invertebrate Traces}

In this section we show some of the invertebrate trace fossils that occurred in association with the ornithopod and theropod tracks at the tracksite in the Cantwell Formation and compare them to modern equivalents (Figs. DR2-DR6).

These trace fossils represent the behaviors of such invertebrates as mud-loving beetles, bugs, mole crickets, nematodes, oligochaetes, as well as other arthropods and worms. All of these traces are found on track surfaces, adjacent to tracks, and over much of the surface of the levee not destroyed by trampling.

The association of high-density dinosaur tracks and surface and shallow surface invertebrate traces that forms the megatracksite were likely produced during the warmer seasons of the year, such as summer or early fall. During this time, insects were very active and occurred in great abundance, during which time they gained body size, reproduced, laid eggs, and larvae or nymphs hatched and prepared to overwinter in states of torpor and inactivity. Our interpretation is based on the present-day timing, diversity, distribution, and behavior of invertebrates and traces in similar environments and climatic settings (e.g., Cloudsley-Thompson, 1962; Brinkhurst, 1974; Roberts, 1977; Hobbs, 1981; Wetzel, 1983; Smith, 1986; Ward, 1992; Merritt and Cummins, 1996; Wallace and Anderson, 1996; Buss et al., 2002; Sinclair et al., 2003; Hanks, 2007; Danks, 2008;

Kivimagi et al, 2008; Ditrich and Papácek, 2009; Walters et al., 2009; Bale and Hayward, 2010; Miller, 2010).

\section{References}

Bale, J.S., and Hayward, S.A.L., 2010, Insect overwintering in a changing climate: The Journal of Experimental Biology, v. 123, p. 980-994.

Brinkhurst, R.O., 1974, The benthos of lakes. Macmillan Press, London, 190 p.

Buss, E.A., Capinera, J.L., and Leppla, N.C., 2002, Pest mole cricket management. University of Florida Extension, 5 p.

Cloudsley-Thompson, J.L., 1962, Microclimates and the distribution of terrestrial arthropods: Annual Review of Entomology, v. 7, 199-222. 
Danks, H.V., 2008, Aquatic insect adaptations to winter cold and ice, in Lancaster, J., and Briers, R.A., eds., Aquatic Insects-Challenges to Populations: Proceedings of the Royal Entomological Society’s 24th Symposium, CABI International, Oxfordshire, p. 1-19.

Ditrich, T., and Papácek, M., 2009, Effective strategy of the overwintering of semiaquatic bugs: overwintering of Velia caprai (Heteroptera: Gerromorpha: Veliidae): Journal of Natural History, v. 43, p. 529-543.

Hanks, H.V., 2007, How aquatic insects live in cold climates: Canadian Entomology, v. 139, p. 443-471.

Hobbs, H.H., Jr., 1981, The crayfishes of Georgia. Smithsonian Contributions to Zoology No. 166, $166 \mathrm{p}$.

Kivimagi, Ploomi, A., Luik, A., Jogar, K., Sibul, I., and Kuusik, A., 2008, Cold-hardening of the ground beetle Carabus granulatus L. (Coleoptera: Carabidae): ZemdirbysteAgriculture, v. 95, p. 428-432.

Merritt, R. W., and Cummins, K. W. (eds.), 1996, An Introduction to the Aquatic Insects of North America, 3rd edition: Iowa, Kendall/Hunt Publishing Company, 862 p.

Miller, F., 2010, Overwintering Strategies of Insects and Implications for Integrated Pest Management. http://www.mortonarb.org/tree-plantadvice/article/16894/overwintering-strategies-of-insects-and-implications-forintegrated-pest-management.html

Roberts, M., 1977, Overwintering Strategies in New Zealand Insects: Tuatara, v. 23, p. 1-10.

Sinclair, B.J., Addo-Bediako, A., and Chown, S.L., 2003, Climatic variability and the evolution of insect freeze tolerance: Biology Reviews, v. 78, p. 181-195.

Smith, K.G.V., 1986, A Manual of Forensic Entomology. Cornell University Press, New York, NY. 205 p.

Ward, J.V., 1992, Aquatic Insect Ecology, 1. Biology and Habitat. John Wiley and Sons, Inc., New York, 438 pp.

Wallace, J.B., and Anderson, N.H., 1996, Habitat, life history, and behavioral adaptations of aquatic insects, in Merritt, R. W., and Cummins, K. W., eds., An Introduction to the Aquatic Insects of North America, 3rd edition: Kendall/Hunt Publishing Company, Iowa, p. 41-73.

Walters, K.R., Jr., Sformo, T., Barnes, B.M., and Duman, J.G., 2009, Freeze tolerance in an arctic Alaska stonefly: The Journal of Experimental Biology, v. 212, v. 305-312.

Wetzel, R.G., 1983, Limnology, 2nd edition. Saunders Publishing, Philadelphia, 767 p. 

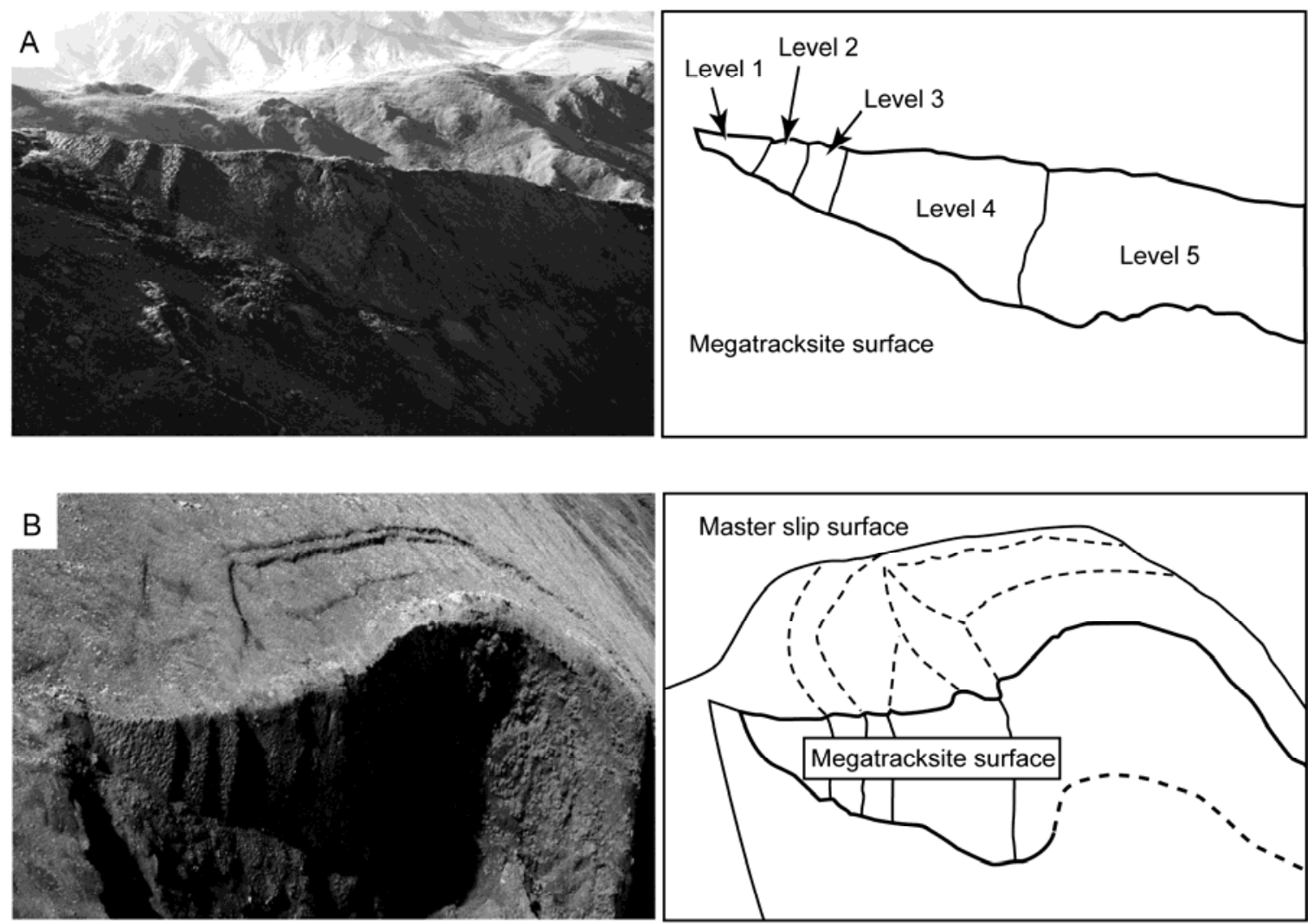

Figure DR1. A: Photograph of most of the megatracksite discussed in this report. Photograph shows five levels across surface. B: shows the cause of the five levels shown in A as the result of displacement of the original bedding plane by slumping. 

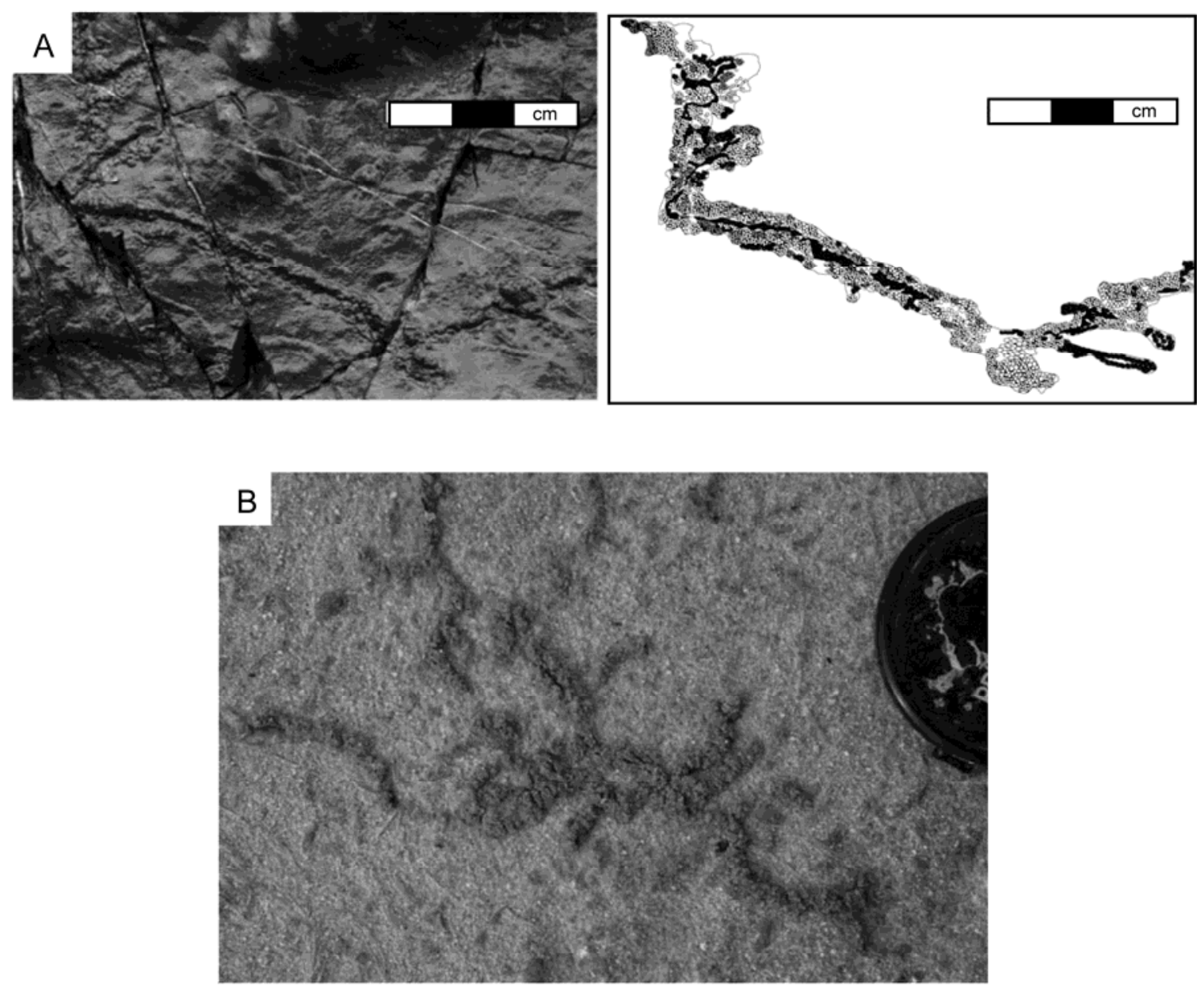

Figure DR2. A: Shallow subsurface trace fossil and line drawing from the track-bearing surface interpreted to have been produced by mud-loving beetles (Coleoptera: Heteroceridae). The trace fossil is convex epirelief in nature. B: Example of a mud-loving beetle (Coleoptera:

Heteroceridae) burrow from the shoreline of the Kalawereenia River near the shoreline of Lake Eyre, South Australia, Australia. This burrow was produced just below the sediment surface, near the sediment-water-air interface as an open burrow in which the surface was pushed upward by the tracemaker to produce a texture of high density of small pustules. 

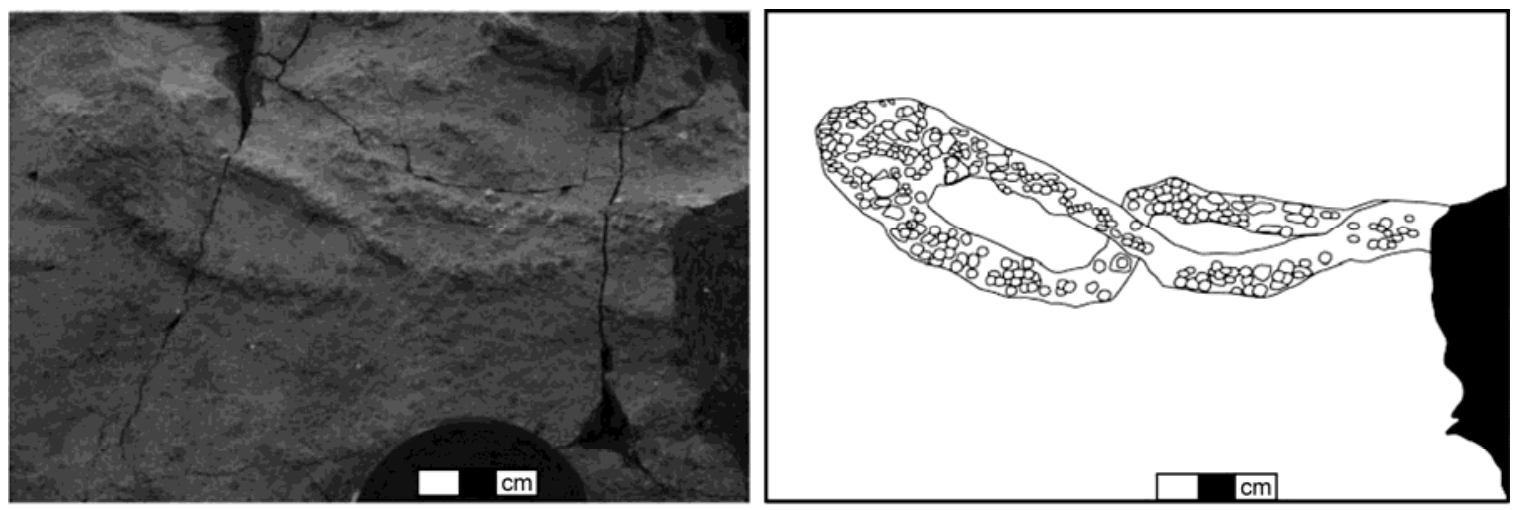

Figure DR3. Shallow subsurface trace fossil and line drawing from the track-bearing surface interpreted to have been produced by a mole cricket (Insecta: Gryllotalpidae). The trace fossil is convex epirelief in nature.
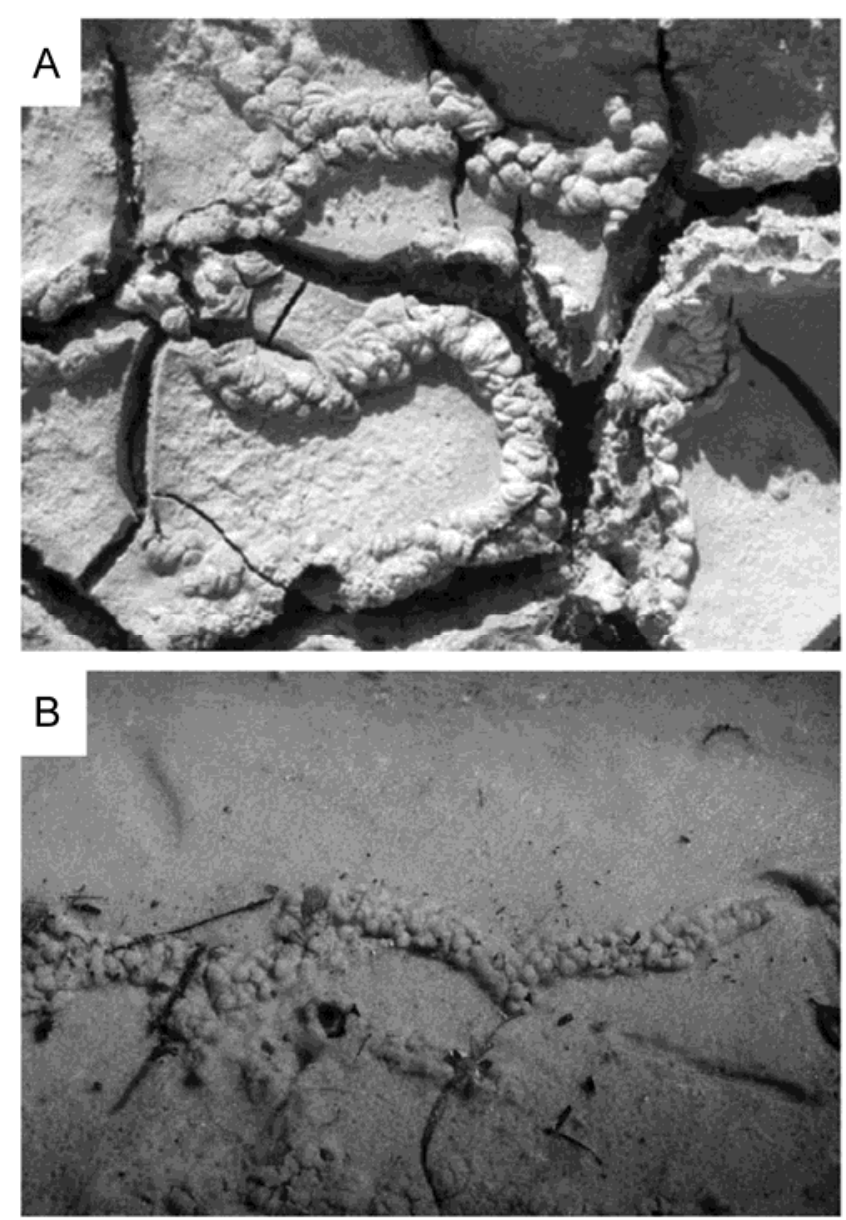

Figure DR4. Examples of a mole cricket (Insecta: Gryllotalpidae) burrows. A) Mole cricket burrow from the shoreline of the Neales River near the shoreline of Lake Eyre, South Australia, Australia. This burrow was produced just below the sediment surface, near the sediment-water-air interface as an open burrow in which the surface was pushed upward by the tracemaker to 
produce a texture of low density of large pustules. Burrow diameter $\sim 1.5 \mathrm{~cm}$. Photo by Mark Reilly. B) Mole cricket burrow from Florida in a sandy-clayey soil. Photo courtesy of Charley Eiseman.
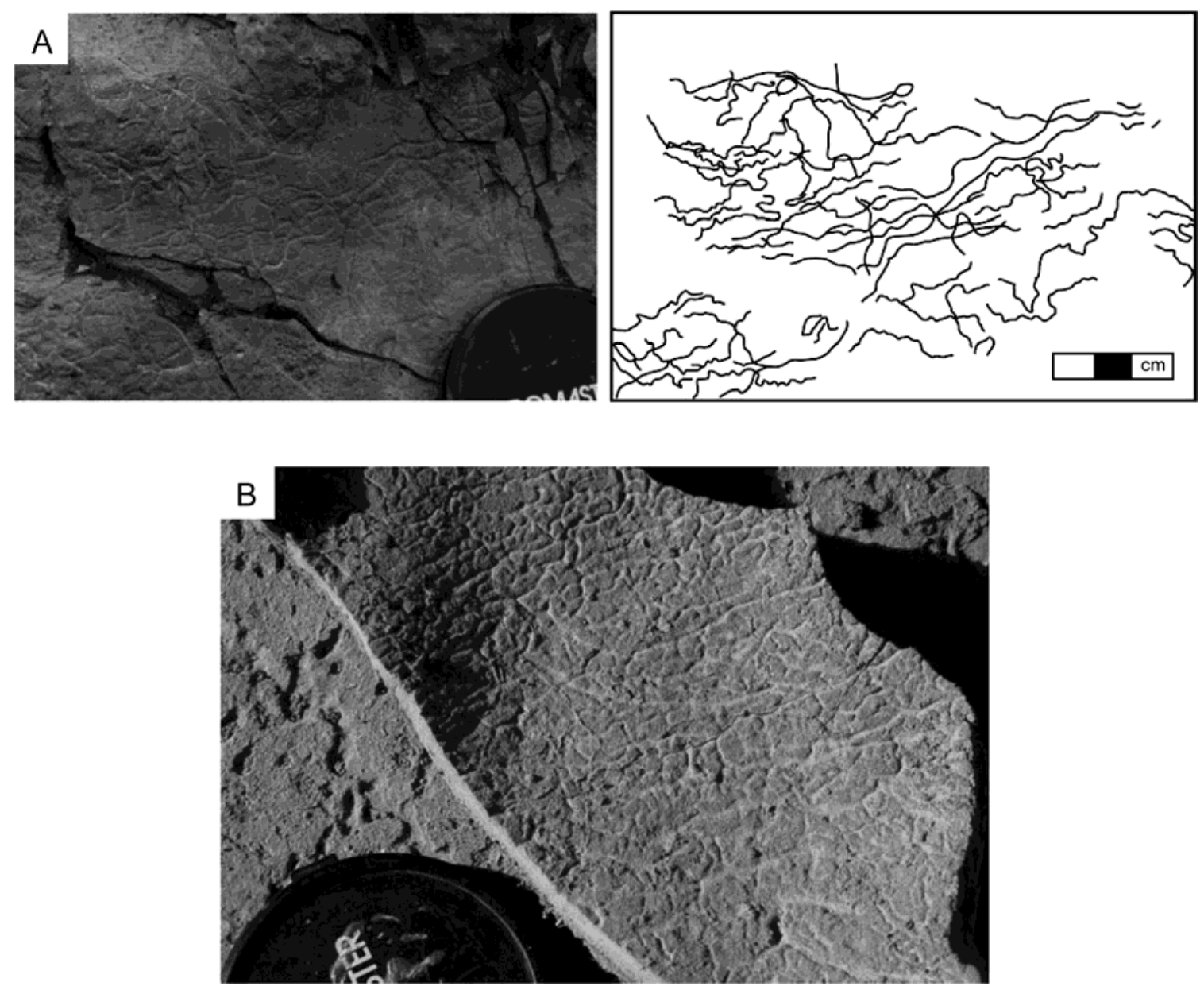

Figure DR5. A: Shallow surface trails and line drawing assigned to Haplotichnus isp. from the track-bearing surface interpreted to have been produced by insect larvae similar to midge flies (Insecta: Diptera) found inside a hadrosaurid footprint. These trace fossils are concave epirelief in nature. B: Example of midge fly larva (Insecta: Diptera) surface trails in an ephemeral stream channel in the area of the San Rafael Swell in southeastern Utah, produced in late summer. These trails are on a piece of desiccated sandy mud that curled on the edges. These trails were produced as the water level neared or was at the sediment-water-air interface. Lens cap $6 \mathrm{~cm}$ in diameter. 

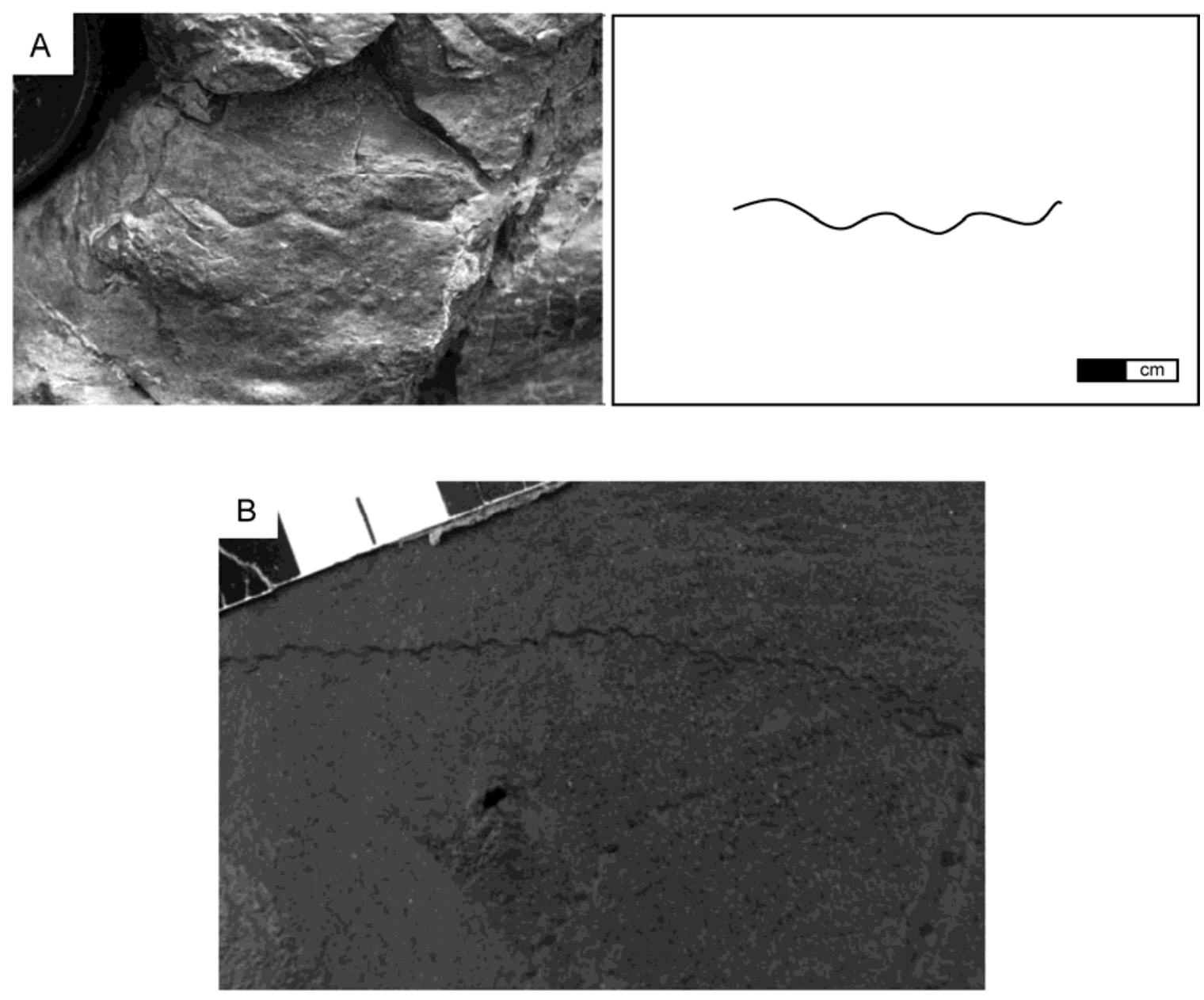

Figure DR6. A: Shallow surface trail and line drawing from the track-bearing surface interpreted to have been produced by a nematode (Animalia: Nematoda) or an aquatic oligochaete (Animalia: Oligochaeta). This trace fossil is concave epirelief in nature. B: Shallow surface trail produced by a nematode (Animalia: Nematoda) from the East fork of the Toklat River, Denali National Park and Preserve, Alaska. This trail was produced as the water level was at the sediment-waterair interface. Scale in centimeters. 